\title{
Comparing the fatigability of paraspinal muscles between sides and curve levels while performing a modified side plank in patients with adolescent idiopathic scoliosis
}

\author{
Alan Richter", Eric C Parent, Gregory Kawchuk, Marc Moreau \\ From 11th International Conference on Conservative Management of Spinal Deformities - SOSORT 2014 \\ Annual Meeting \\ Wiesbaden, Germany. 8-10 May 2014
}

\section{Background}

While many studies have been performed on the effects of exercise on Adolescent Idiopathic Scoliosis (AIS) little research has been done into the underlying muscle physiology. Studies have suggested a fibre type imbalance, however, the implications of this difference as reflected through fatiguability have not been studied. The slope of the median frequency of the surface electromyographic (EMG) signal is a useful tool in determining the fatigability of muscles.

\section{Aim}

To compare the fatigability of paraspinal muscles between levels and sides in patients with AIS.

\section{Design}

Cross-sectional study

\section{Methods}

Subjects with AIS were recruited from our specialized scoliosis clinic. Subjects performed 3 'modified side planks' on both left and right sides. Bipolar sEMG electrodes were placed on either side of the spine at the upper end vertebrae(UEV), apex, and lower end vertebrae (LEV). Raw EMG muscle activity was recorded. The slope of the median frequency of the EMG power spectrum was extracted using Matlab. A repeated measures side-by-level ANOVA was performed to detect differences in the average of the closest 2 out 3 fatigue trials between sides and levels. A paired t-test was performed to determine if there were differences in trial duration between left and right planks

\section{Results}

Thirteen subjects were recruited (10 females) with a mean age of $13.6 \pm 1.6$ years and a mean BMI of $19.76 \pm 3.8 \mathrm{~kg} / \mathrm{m}^{2}$. Mean Cobb angle was $25 \pm 10.3$ degrees. No significant interaction or main effects were found in fatigue measurements between sides and levels. Mean slope of median frequency over sides and levels was $0.023 \pm 0.103$ for left plank and $0.108 \pm 0.21$ for right plank. There were no significant differences between left $(55.46 \mathrm{sec} \pm 19.39)$ and right (58.31sec \pm 19.61$)$ plank mean durations.

\section{Conclusions}

The side plank did not create enough fatigue in paraspinal muscles when using sEMG as to measure the slope of the median frequency to detect differences between levels and sides. Future work will address the study objectives using the Sorensen test to generate more paraspinal fatigue.

Published: 4 December 2014

\section{References}

1. Mannion AF, Méier M, Grob D, Muntener M: Paraspinal muscle fibre type alterations associated with scoliosis: an old problem revisited with new evidence. Eur. Sp. J 1998, 7(4):289-293.

2. Cifrek M, Medved V, Tonković S, Ostojić S: Surface EMG based muscle fatigue evaluation in biomechanics. Clin Biomech (Bristol, Avon) 2009, 24(4):327-340.

University of Alberta, Edmonton, Canada 
doi:10.1186/1748-7161-9-S1-011

Cite this article as: Richter et al: Comparing the fatigability of

paraspinal muscles between sides and curve levels while performing a

modified side plank in patients with adolescent idiopathic scoliosis.

Scoliosis 2014 9(Suppl 1):011.

Submit your next manuscript to BioMed Central and take full advantage of:

- Convenient online submission

- Thorough peer review

- No space constraints or color figure charges

- Immediate publication on acceptance

- Inclusion in PubMed, CAS, Scopus and Google Scholar

- Research which is freely available for redistribution

Submit your manuscript at 